\title{
Cell Growth
}

National Cancer Institute

\section{Source}

National Cancer Institute. Cell Growth. NCI Thesaurus. Code C16402.

The complex series of phenomena occurring after cell division and before cell death. 